\title{
Phenolic Compound Profiles of Two Common Beans Consumed by Rwandans
}

\author{
Owino Joseph ${ }^{1 *}$, Mukashyaka Phelomene', Ndayisaba Helene' ${ }^{1}$, Habimana Valens ${ }^{1}$, \\ Ongol Martin Patrick ${ }^{2}$, Dil Thavarajah ${ }^{3}$, Pushparajah Thavarajah ${ }^{3}$

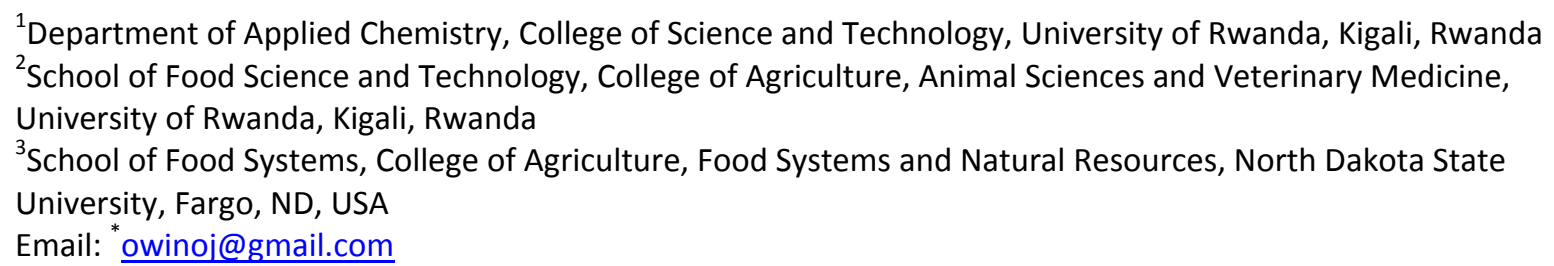

Received 2 July 2014; revised 12 August 2014; accepted 29 August 2014

Copyright (C) 2014 by authors and Scientific Research Publishing Inc.

This work is licensed under the Creative Commons Attribution International License (CC BY). http://creativecommons.org/licenses/by/4.0/

(c) (i) Open Access

\begin{abstract}
Legumes are high-protein, medium-energy and micronutrient-rich food consumed in many parts of the world including Africa. This study evaluated the levels of specific phenolic compounds in three legumes. Two varieties of the common bean, (Phaseolus vulgaris L.) soybeans (Glycine max L.), and peas (Pisum sativum L.) from Rwanda were analyzed using high performance liquid chromatography with diode array detection. The phenolic compounds were identified by comparison to the chromatographic retention times and UV spectra of known reference compounds. This study results clearly shows the presence of 11 different phenolic compounds in common beans: gallic acid, (+)-catechin, (-)-epicatechin, caffeic acid, o-coumaric acid, chlorogenic acid, quercetin, 4-hydrobenzoic acid, syringic acid, ferulic acid and vanillic acid. The concentration ranged from 0.59 to $2.27 \mathrm{mg} / \mathrm{kg}$ for epicatechin. High levels of catechin $(13.5$ to $57.9 \mathrm{mg} / \mathrm{kg})$ ferulic acid $(26.1$ to $47.6 \mathrm{mg} / \mathrm{kg}$ ) were also observed. Therefore, the results of this study show that Rwandan common beans are a good source of phenolic acids in particular catechins and ferulic acid.
\end{abstract}

\section{Keywords}

Common Bean, Phenolic Compounds, Rwanda, Identification and Quantification

\section{Introduction}

Legumes are a source of proteins, minerals, and vitamins for millions of world populations. The common bean

${ }^{*}$ Corresponding author.

How to cite this paper: Joseph, O., Phelomene, M., Helene, N., Valens, H., Patrick, O.M., Thavarajah, D. and Thavarajah, P. (2014) Phenolic Compound Profiles of Two Common Beans Consumed by Rwandans. American Journal of Plant Sciences, 5, 2943-2947. http://dx.doi.org/10.4236/ajps.2014.520310 
(Phaseolus vulgaris L.), one of the food legumes, is a part of daily diets of African, Asian and South American populations. Common beans being a member of Leguminacea family fixing atmospheric nitrogen provide significant crop rotational advantages, and a contributor towards agricultural sustainability in many parts of the world [1].

Common beans are also a rich source of phytochemicals. Consumption of common beans rich in phytochemicals promotes human health. Among phytochemicals the phenolic class of compounds such as epicatechin, epigallocatechin gallate and catechin flavonoids protect against neurotoxic oxidative stresses. Epicatechins are also able to cross the blood-brain barrier [2] to reduce lipid peroxidation and inhibit platelet aggregation. In diabetic red blood cells, epicatechins increase acetylcholinesterase activity [3]. In addition, other phenolic compounds such as flavonoids have been shown to protect against lung diseases and a range of cancers [4].

Besides positive nutritional benefits of phenolic compounds, polymeric forms of phenolic compound or polyphenols exert negative health effects on protein digestibility and $\alpha$-amylase activities. For example, heat-stable tannins inhibit pectinases, cellulase, amylases, $\beta$-galactosidases, lipases and several proteolytic enzyme activities. Iron $(\mathrm{Fe})$ and zinc $(\mathrm{Zn})$ mineral micronutrient bi-availabilities have been reduced in common beans with high concentration of certain phenolic compounds [5]. Polyphenols are also a contributor towards off colors and undesirable flavors in beans and other foods.

Common bean is a part of daily diet of majority of Rwandans. It is estimated that Rwandan consumes $60 \mathrm{~kg}$ common beans per person per year [6]. With significant common bean consumption by Rwandans this study was carried out to determine type and concentrations of phenolic compounds in most widely consumed bean varieties. In addition, common bean phenolic compounds types and concentrations were compared with those of soybean and peas grown in Rwanda.

\section{Materials and Methods}

\subsection{Study Samples}

The legumes verities of pink and blue common beans of one kg were purchased in April 2013 from the local market within two km radius of the University of Rwanda Campus in Kigali, Rwanda. They were washed, sorted, and powdered using a domestic grinder (Philips, Model No. 2161, Netherlands). The powered samples kept in refrigerator $4^{\circ} \mathrm{C}$ until sample analysis.

\subsection{Chemicals and Reagents}

All chemicals and reagents used were purchased from Sigma-Aldrich (St. Louis, MO, USA) and used without further purification. Ultra-pure water was purchased from Milli-Q plus system from Millipore (Billerica, MA, USA).

\subsection{Extraction}

Six $\mathrm{ml}$ of $95 \%$ ethanol was added to $0.6 \mathrm{~g}$ of finely ground dry samples, followed by rigorously mixing (2500 rpm) using a vortex for about 2 minutes. Then the samples were centrifuged at $1400 \mathrm{rpm}$ for 10 minutes at room temperature and the supernatant was taken for further analysis.

\subsection{Chromatographic Conditions}

The sample analysis was performed on a high performance liquid chromatography (HPLC) with PDA detection (Shimadzu Scientific Instruments, Kyoto, Japan). The analyte separation column was Shim-Pack VP-ODS C18 column $(250 \mathrm{~mm} \times 4.6 \mathrm{~mm}, 5 \mu \mathrm{m})$ Shim-Pack VP, Shimadzu Scientific Instruments, Kyoto, Japan. The DAD detector was applied to scan the phenolic compounds of interest to ascertain their maximum absorbance wavelengths and acquire other spectral information within a range of 200 to $400 \mathrm{~nm}$. A gradient solvent system was employed with solvent A being water-acetic acid (97:3, v/v) and solvent $B$ being acetonitrile. The elution profile had the following proportions (v/v) of solvent B: $0.00-5.00 \mathrm{~min}, 0 \%-8.5 \%$; $5.00-16.50 \mathrm{~min}, 8.5 \%-2.0 \%$; 16.50 - $35.00 \mathrm{~min}, 2.0 \%$ - 18\%; 35.00 - $50.00 \mathrm{~min}, 18 \%$ - 20\%; 50.00 - $65.00 \mathrm{~min}, 20 \%$ - 30\%; 65.00 - 70.00 $\min , 0 \%-30 \%$. The separated peaks were identified at 255, 260, 275 280, 304, 324 and $360 \mathrm{~nm}$. The column temperature was maintained at $30^{\circ} \mathrm{C}$ with a flow rate of $0.8 \mathrm{ml} / \mathrm{min}$. All the prepared solutions and samples were filtered through $0.25 \mu \mathrm{m}$ membranes (Minisart, Sartorium Stedim Biotech, Russia) prior to analysis. 


\subsection{Calibration Curves}

Solutions of the phenolic standards were prepared in the mobile phase. Separate calibration curves were used for phenolic compounds at four different concentrations. Quantifications were validated using inter laboratory analysis of selected phenolic compounds at both at University of Rwanda (UOR), Kigali, Rwanda and North Dakota State University (NDSU), ND, USA. All samples were analyzed in triplicate.

\subsection{Statistical Analysis}

The results were analyzed by analysis of variance and calculation of correlations and regression with SPSS 16.0 statistical software (IBM Corporation, USA). Differences between means were evaluated using the Duncan's multiple range test. The difference was considered significant $\mathrm{p}<0.05$.

\section{Results and Discussion}

\subsection{Phenolic Compounds Separation and Identification}

The chromatographic conditions of the phenolic compounds were optimized prior to sample analysis. The peaks of all analytes were well resolved, and a representative chromatogram is shown in Figure 1. The standard curves of all phenolic compounds correlations were 0.99 or higher. Therefore, we are certain that peak identification and sample quantification are accurate. Inter laboratory validation between the UOR and NDSU also confirmed selected peak identification and quantification. Chromatographic identification and confirmation of phenolic compounds were based on comparing retention times with authentic standards. The relative concentrations at different wavelengths were calculated from the calibration curves [7].

\subsection{Bean Phenolic Compound Quantification}

Beans are good source of phenolic compounds. In this study sample phenolic compound detailed results are shown in Table 1. The levels of phenolic compound varied from $16.78-25.01 \mathrm{mg} / \mathrm{kg}$ for gallic acid, 18.18 $29.64 \mathrm{mg} / \mathrm{kg}$ for 4 hydroxy benzoic acid, 10.69 - $13.33 \mathrm{mg} / \mathrm{kg}$ for vanillic acid, 23.17 - $24.06 \mathrm{mg} / \mathrm{kg}$ for chlorogenic acid, 11.8 - $41.9 \mathrm{mg} / \mathrm{kg}$ for caffeic acid, 14.1 - $31.3 \mathrm{mg} / \mathrm{kg}$ for syringic acid, 13.5 - $57.9 \mathrm{mg} / \mathrm{kg}$ for catechin, 0.59 - $2.27 \mathrm{mg} / \mathrm{kg}$ for epicatechin, 12.57 - $27.1 \mathrm{mg} / \mathrm{kg}$ for o-coumaric acid, 26.1 - 47.6 for ferulic acid and 16.73 - $19.23 \mathrm{mg} / \mathrm{kg}$ for quercetin. From the results there was no significant difference $(\mathrm{p}>0.05)$ in epicatechin, quercetin, catechin and ferulic acid in the four samples analyzed implying that consumption of the samples will result in the same amount of the named phenolic compounds. In blue dry beans, catechin had the highest concen-

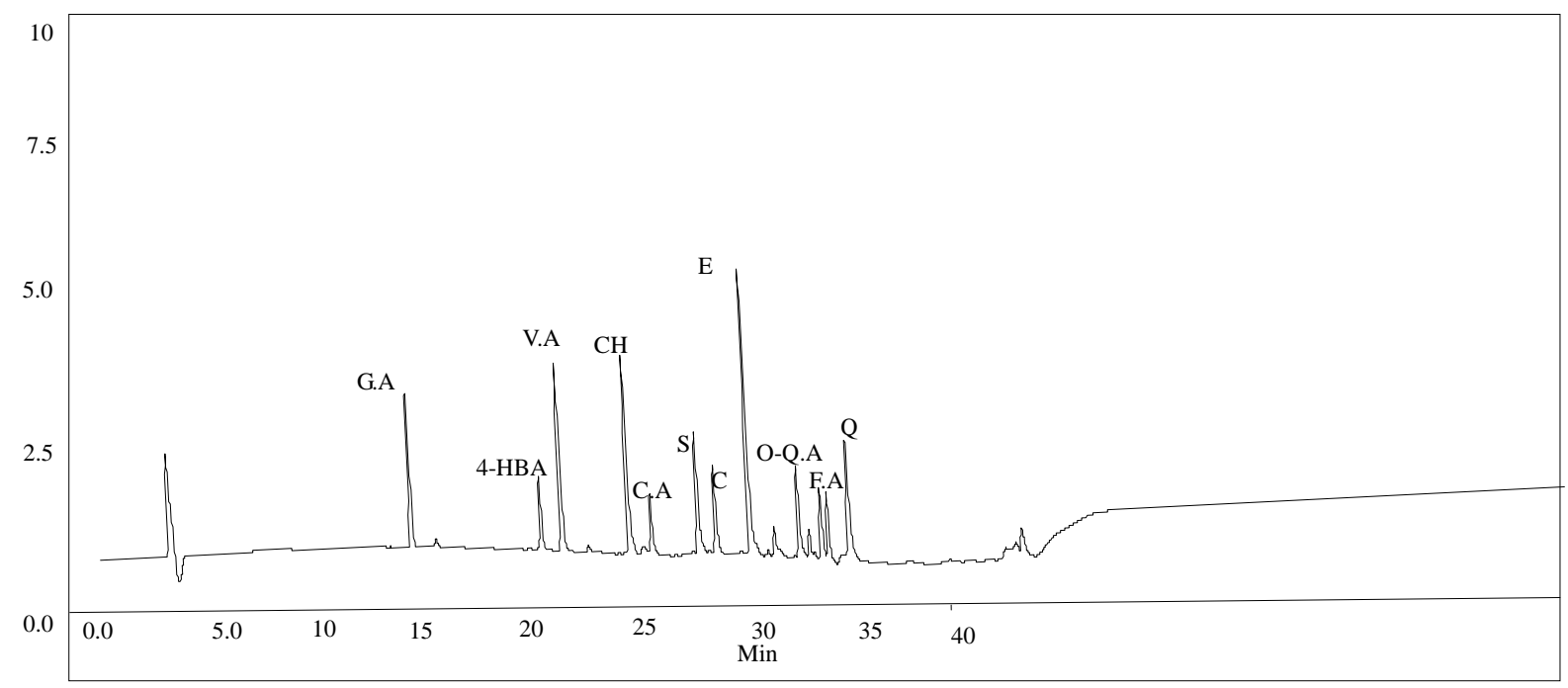

Figure 1. Representative HPLC chromatogram of 11 different phenolic compounds. GA: Gallic Acid, 4-HBA: 4-Hydroxy Benzoic Acid, V.A: Vanillic Acid, CH: Chlorogenic, C.A: Caffeic Acid, S: Syringic, C: Catechin, E: Epicatechin, O-Q.A: O-Qoumaric Acid, F.A: Ferulic Acid, Q: Quercetin. 
Table 1. Composition of the phenolic compounds.

\begin{tabular}{|c|c|c|c|c|c|c|c|c|c|c|c|}
\hline SAMPLES & $\begin{array}{l}\text { Gallic } \\
\text { acid }\end{array}$ & $\begin{array}{l}\text { 4-Hydroxy } \\
\text { benzoic acid }\end{array}$ & $\begin{array}{c}\text { Vanillic } \\
\text { acid }\end{array}$ & $\begin{array}{c}\text { Chlorogenic } \\
\text { acid }\end{array}$ & $\begin{array}{c}\text { Caffeic } \\
\text { acid }\end{array}$ & $\begin{array}{l}\text { Syringic } \\
\text { acid }\end{array}$ & Catechin & Epicatechin & $\begin{array}{c}\text { Coumaric } \\
\text { acid }\end{array}$ & $\begin{array}{c}\text { Ferulic } \\
\text { acid }\end{array}$ & Quercetin \\
\hline BLUE BEAN & $\begin{array}{c}16.78^{\mathrm{a}} \pm \\
0.24\end{array}$ & $\begin{array}{c}26.84^{\mathrm{a}} \pm \\
1.15\end{array}$ & $\begin{array}{c}10.69^{\mathrm{a}} \pm \\
0.07\end{array}$ & $\begin{array}{c}23.36^{\mathrm{a}} \pm \\
0.53\end{array}$ & $\begin{array}{c}41.9^{\mathrm{c}} \pm \\
1.04\end{array}$ & $\begin{array}{r}14.4^{\mathrm{a}} \\
+1.11\end{array}$ & $\begin{array}{c}57.0^{\mathrm{c}} \pm \\
0.80\end{array}$ & $\begin{array}{c}1.10^{\mathrm{b}} \pm \\
0.00\end{array}$ & $\begin{array}{c}12.57^{\mathrm{a}} \pm \\
0.37\end{array}$ & $\begin{array}{c}26.1^{\mathrm{a}} \pm \\
0.01\end{array}$ & $\begin{array}{c}16.77^{\mathrm{a}} \pm \\
0.24\end{array}$ \\
\hline PINK BEAN & $\begin{array}{c}25.01^{\mathrm{c}} \pm \\
2.77\end{array}$ & $\begin{array}{c}27.17^{\mathrm{a}} \pm \\
0.54\end{array}$ & $\begin{array}{c}11.54^{\mathrm{a}} \pm \\
0.08\end{array}$ & $\begin{array}{c}23.59^{\mathrm{a}} \pm \\
0.08\end{array}$ & $\begin{array}{c}25.5^{b} \pm \\
3.20\end{array}$ & $\begin{array}{c}14.1^{\mathrm{a}} \\
\pm 0.34\end{array}$ & $\begin{array}{c}13.5^{\mathrm{a}} \pm \\
0.50\end{array}$ & $\begin{array}{c}2.27^{\mathrm{c}} \pm \\
0.04\end{array}$ & $\begin{array}{c}16.66^{\mathrm{a}} \pm \\
0.65\end{array}$ & $\begin{array}{c}36.0^{\mathrm{b}} \pm \\
1.44\end{array}$ & $\begin{array}{c}17.21^{\mathrm{a}} \pm \\
0.15\end{array}$ \\
\hline SOYA & $\begin{array}{c}20.28^{\mathrm{b}} \pm \\
0.09\end{array}$ & $\begin{array}{c}18.18^{\mathrm{a}} \pm \\
0.53\end{array}$ & $\begin{array}{c}10.91 \mathrm{a} \pm \\
0.16\end{array}$ & $\begin{array}{c}23.17^{\mathrm{a}} \pm \\
0.08\end{array}$ & $\begin{array}{c}40.3^{\mathrm{C}} \pm \\
9.47\end{array}$ & $\begin{array}{c}18.7^{\mathrm{b}} \pm \\
0.25\end{array}$ & $\begin{array}{c}57.9^{c} \pm \\
1.64\end{array}$ & $\begin{array}{c}1.06^{\mathrm{b}} \pm \\
0.08\end{array}$ & $\begin{array}{c}27.1^{\mathrm{a}} \pm \\
1.19\end{array}$ & $\begin{array}{c}27.1^{\mathrm{a}} \pm \\
1.19\end{array}$ & $\begin{array}{c}16.73^{\mathrm{a}} \pm \\
2.49\end{array}$ \\
\hline PEA & $\begin{array}{c}20.48^{\mathrm{b}} \pm \\
0.67\end{array}$ & $\begin{array}{c}29.64^{\mathrm{a}} \pm \\
3.10\end{array}$ & $\begin{array}{c}13.33^{\mathrm{b}} \pm \\
1.85\end{array}$ & $\begin{array}{c}24.06^{\mathrm{a}} \pm \\
1.10\end{array}$ & $\begin{array}{c}11.8^{\mathrm{a}} \pm \\
0.45\end{array}$ & $\begin{array}{c}31.3^{\mathrm{C}} \pm \\
2.13\end{array}$ & $\begin{array}{c}18.1^{\mathrm{b}} \pm \\
3.83\end{array}$ & $\begin{array}{c}0.59^{\mathrm{a}} \pm \\
0.42\end{array}$ & $\begin{array}{c}15.34^{\mathrm{a}} \pm \\
0.02\end{array}$ & $\begin{array}{c}47.6^{\mathrm{c}} \pm \\
3.39\end{array}$ & $\begin{array}{c}19.23^{\mathrm{a}} \pm \\
1.83\end{array}$ \\
\hline
\end{tabular}

tration of $57 \mathrm{mg} / \mathrm{kg}$ while epicatechin had the lowest concentration $1.1 \mathrm{mg} / \mathrm{kg}$. Similar trend was observed in a study of quantitation of phenolics from the seeds of green beans in which levels of catechin was $407.5 \mathrm{mg} / \mathrm{kg}$ while epicatechin was $207.6 \mathrm{mg} / \mathrm{kg}$ [8]. In pink dry beans ferulic acid had the highest concentration of $36 \mathrm{mg} / \mathrm{kg}$ while epicatechin had the lowest concentration of $2.7 \mathrm{mg} / \mathrm{kg}$. In soybean, catechin had the highest concentration of $57.9 \mathrm{mg} / \mathrm{kg}$ while the lowest concentration was observed in epicatechin at $1.06 \mathrm{mg} / \mathrm{kg}$. For pea, highest concentration was seen in ferulic acid at $47.6 \mathrm{mg} / \mathrm{kg}$ and the lowest was epicatechin at $0.59 \mathrm{mg} / \mathrm{kg}$. The low levels of epicatechin could be attributed to an epimerization reaction which converts epicatechin to its epimer catechin during the extraction process [9].

Only p-coumaric and ferulic acid were reported in a study [10], from the flour and hull of the navy beans. In a study on phenolic acids content of fifteen dry edible bean varieties, caffeic acid was quantified at $1.1 \mathrm{mg} / 100 \mathrm{mg}$ in black beans, p-coumaric acid was $12.4 \mathrm{mg} / 100 \mathrm{~g}$, ferulic acid was $26.6 \mathrm{mg} / 100 \mathrm{~g}$ and sinapic acid $9.4 \mathrm{mg} /$ $100 \mathrm{mg}$ [11]. The observed values are much higher for caffeic and ferulic acid compared to the study samples. This difference can be attributed to various factors such as variety, assay procedure, growing and storage conditions, agronomic practices (irrigation, fertilization, pest management), maturity at harvest, post harvest storage and climatic conditions [12]-[14].

Most studies in literature reports on the total phenolic content, which makes it not possible for, direct comparison with our study. However, this may be the first study from Rwanda reporting detailed phenolic compound results. Since polyphenols exert both beneficial and negative effects, further studies using common bean phenolic compounds on cell culture, animal models and human subjects will provide real human nutrition benefits.

\section{Conclusion}

Eleven phenolic compounds in common bean samples were analyzed and quantified using high-performance liquid chromatography-diode array detection. This study shows that Rwandan beans are a good source of phenolic compounds in particular catechins and ferulic acid.

\section{References}

[1] Broughton, W.J., Hernandez, G., Blair, M., Beebe, S., Gepts, P. and Vanderleyde, J. (2003) Beans (Phaseolus spp.)— Model Food Legumes. Plant and Soil, 252, 55-128. http://dx.doi.org/10.1023/A:1024146710611

[2] Vivanco, J.M., Bais, H.P., Vepachedu, R., Gilroy, S. and Callaway, R.M. (2003) Allelopathy and Exotic Plant Invasion: From Molecules and Genes to Species Interactions. Science, 13, 77-80.

[3] Maria, A., Janeiro, P. and Oliveira, B. (2004) Catechin Electrochemical Oxidation Mechanisms. Analytica Chimica Acta, 518, 109-115. http://dx.doi.org/10.1016/j.aca.2004.05.038

[4] Woods, R.K., Raven, J.M., Wolfe, R., Ireland, P.D., Thien, F.C.K. and Abramson, M.J. (2003) Food and Nutrient Intakes and Asthma Risk in Young Adults. American Journal of Clinical Nutrition, 78, 414-421.

[5] Oatway, L., Vasanthan, T. and Helm, J. (2001) Phytic Acid. Food Reviews International, 17, 419-431. http://dx.doi.org/10.1081/FRI-100108531

[6] MINAGRI (2012) CIA World Factbook. MINAGRI, Rwanda.

[7] Robbins, J.R. and Bean, S.R. (2004) Development of a Quantitative High Performance Liquid Chromatography-Photodiode Array Detection Measurement System for Phenolic Acids. Journal of Chromatography A, 1038, 97-105. http://dx.doi.org/10.1016/j.chroma.2004.03.009

[8] Escarpa, A. and Gonzaez, M.C. (2000) Identification and Quantitation of Phenolics from Green Beans by High-Per- 
formance Liquid Chromatography. Chromatographia, 52, 33-38. http://dx.doi.org/10.1007/BF02490789

[9] Kofink, M., Papagiannopoulos, M. and Galensa, R. (2007) (-)-Catechin in Cocoa and Chocolate: Occurrence and Analysis of an Atypical Flavan-3-ol Enantiomer. Molecule, 12, 1274-1288.

[10] Sosulski, F.W. and Dabroski, K.J. (1984) Composition of Free and Hydrolysable Phenolic Acids in the Flours and Hulls of Ten Legume Species. Journal of Agriculture and Food Chemistry, 32, 131-133. http://dx.doi.org/10.1021/jf00121a033

[11] Luthria, D.L. and Pastor-Corrales, M.A. (2006) Phenolic Acids Content of Fifteen Dry Edible Bean (Phaseolus vulgaris L.) Varieties. Journal of Food Composition and Analysis, 19, 205-211. http://dx.doi.org/10.1016/j.jfca.2005.09.003

[12] Dixon, R.A. and Paiva, N.L. (1995) Stress-Induced Phenylpropanoid Metabolism. Plant Cell, 7, 1085-1097. http://dx.doi.org/10.1105/tpc.7.7.1085

[13] Ninfali, P. and Bacchiocca, M. (2003) Polyphenols and Antioxidant Capacity of Vegetables under Fresh and Frozen Conditions. Journal of Agricultural and Food Chemistry, 51, 2222-2226. http://dx.doi.org/10.1021/jf020936m

[14] Hakkinen, S. and Torronen, R. (2000) Content of Flavonols and Selected Phenolic Acids in Strawberries Vaccinium Species: Influence of Cultivar, Cultivation Site and Technique. Food Reviews International, 33, 517-524. http://dx.doi.org/10.1016/S0963-9969(00)00086-7 
Scientific Research Publishing (SCIRP) is one of the largest Open Access journal publishers. It is currently publishing more than 200 open access, online, peer-reviewed journals covering a wide range of academic disciplines. SCIRP serves the worldwide academic communities and contributes to the progress and application of science with its publication.

Other selected journals from SCIRP are listed as below. Submit your manuscript to us via either submit@scirp.org or Online Submission Portal.
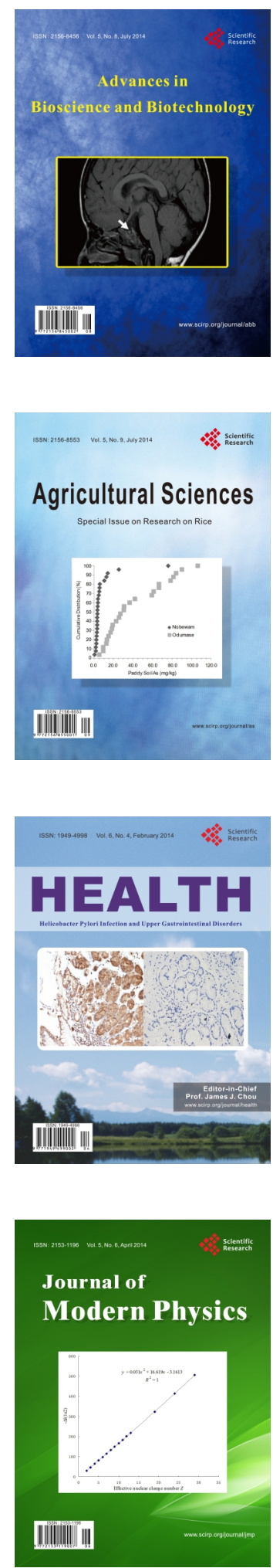
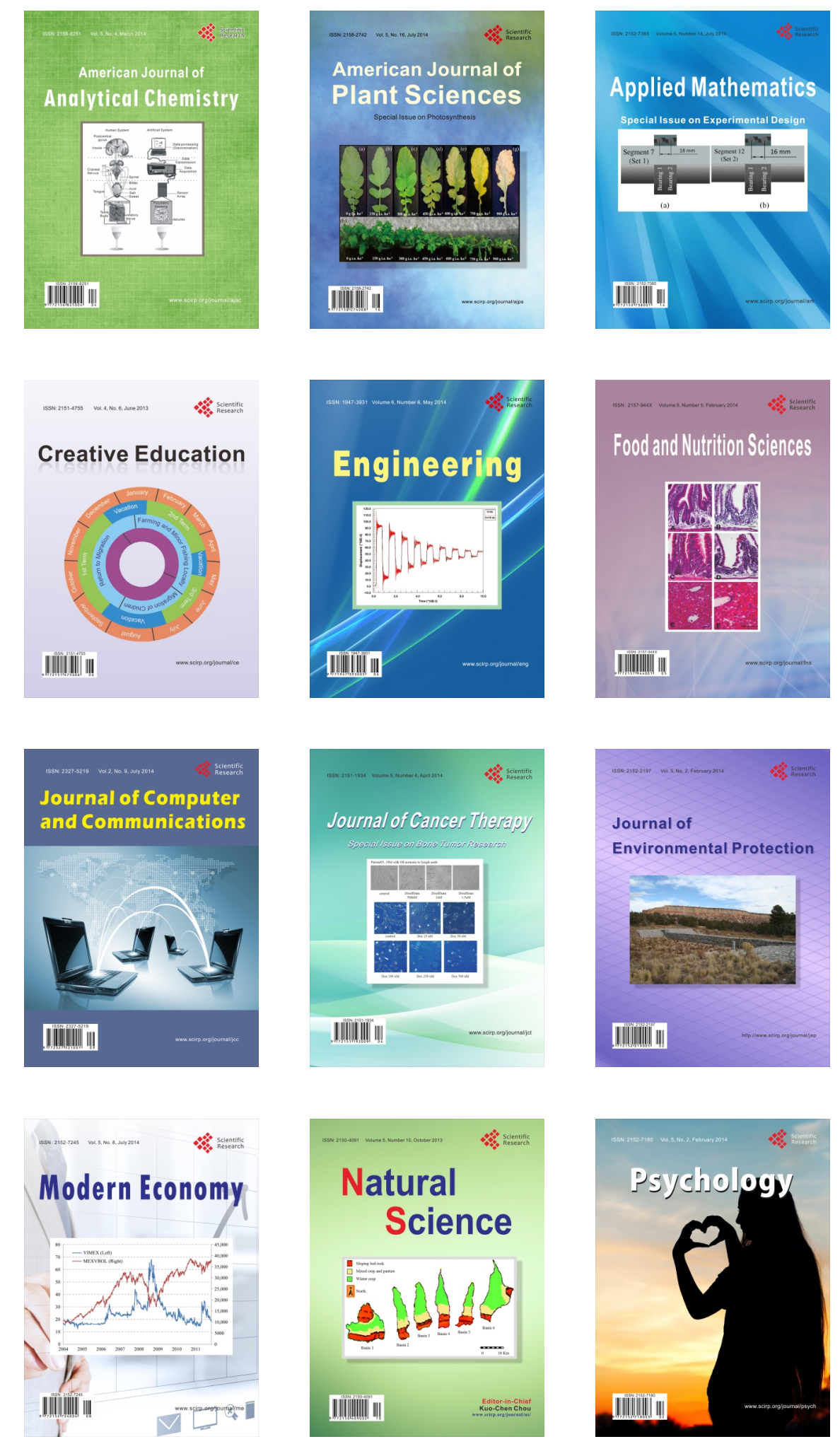